\title{
ASSESSMENT OF QUALITY OF LIFE PATIENTS SUFFERING FROM BREAST CANCER AND LUNG CANCER
}

\author{
Kalajdzic Olivera, ${ }^{1}$ Pavlovic Jelena ${ }^{2}$ \\ ${ }^{1}$ Department of Psychology, University of East Sarajevo, Faculty of Medicine in Foca, Bosnia and Herzegovina \\ ${ }^{2}$ Department of Nursing, University of East Sarajevo, Faculty of Medicine in Foca, Bosnia and Herzegovina \\ Primljen/Received 02. 12. 2020. god. \\ Prihvaćen/Accepted 30. 01. 2021. god.
}

\begin{abstract}
Introduction: Assessment of quality of life is an important subject of research in various disciplines and today it is an integral part of the evaluation of rehabilitation and therapeutic procedures. The aim of the study was to assess the quality of life and to assess the impact of depression on the quality of life in patients with breast cancer and lung cancer.
\end{abstract}

Material and methods: The study included 60 people, of whom 30 were diagnosed with lung cancer and 30 with breast cancer. The questionnaire was constructed by researchers for this research. Quality of Life Assessment Questionnaire SF-36 and assessment of depression, Beck Depression Scale.

Results: The presence of complications is a statistically significant source of differences in the domain of the total physical score, and is not a statistically significant source of differences in other domains from the SF36 questionnaire. Based on the data from the previous table, we can see that the values on the Beck Depression Inventory range from 23 to 35, with $\mathrm{AS}=30.00$ and $\mathrm{SD}=2.584$.

Conclusion: Respondents who have a higher score on the Beck Depression Inventory also have a higher score on the dimension of physical functioning.

Keywords: quality of life, malignant diseases, depression, patients.

\section{INTRODUCTION}

Quality of life is a complex concept dealt with by various scientific disciplines. Health status is an important element of quality of life. One of the indicators of health status is self-assessment of health (1). A narrower term than general quality of life is health-related quality of life (HRQoL). It is a state of well-being that consists of the ability to perform the activities of everyday life and the patient's satis- faction with the degree of functioning and control of the disease. In addition to the four basic dimensions of quality of life, the existence of symptoms and side effects of medical treatments to which the patient is subjected (satisfaction with the treatment, emotional distress, spirituality, financial condition, etc.) is also important $(2,3)$. Quality of life in oncology looks at the subjective experiences of the positive and negative aspects of the disease on physical, emotional, social and cognitive functions, and the frequency of symptoms and side effects of treatment. Quality of life is specific for malignant diseases and is associated with all stages of the disease. Assessment of quality of life is an important subject of research in various disciplines and today it is an integral part of the evaluation of rehabilitation and therapeutic procedures. The issue of personal quality of life factors is very topical in the field of health care of chronic patients, as well as in the general population (4). Technological advances and new diagnostic methods and therapies have resulted in longer survival of patients with breast and lung cancer, and as a result, there is a growing interest in assessing the quality of life of these patients. Nowadays, there is an increasing problem in the competitive healthcare market, the problem of measuring the quality of care for certain diseases, as well as the quality of life (QOL) $(5,6)$. The study aimedto assess the quality of life and to assess the impact of depression on quality of life in patients with breast cancer and lung cancer.

\section{MATERIAL AND METHODS}

\section{Respondents and type of study}

The quality of life study,for patients diagnosed with lung or breast cancer, was designed as a cross-sectional study. The study included 60 people, of whom 30 were diagnosed with lung cancer and 30 with di- 
agnosed breast cancer. The sample included the same number of men and women ( 30 women and 30 men), aged 32 to 83 years. The research was conducted at the University Hospital Foca, Department of Oncology in the period between April and September 2018. All respondents were informed about the goals of the research, and they agreed to participate with written consent.

This study was conducted according to the guidelines laid down in the Declaration of Helsinki, and all procedures involving research study participants were approved by the Ethics Committee of the Faculty of Medicine Foca.

\section{Instruments}

The survey was conducted through a specially constructed questionnaire consisting of several units: sociodemographic characteristics, questionnaire on socio-demographic characteristics of respondents that provides data on personal, socio-status characteristics of respondents relevant to this research (gender, age, education, marital status, employment status, diagnosis, length of chemotherapy and the presence of complications). The questionnaire was constructed by researchers for the purposes of this research. Quality of Life Assessment Questionnaire SF-36 (7). The questionnaire contains 36 questions, which are classified into 8 domains: physical functioning (8 questions), limitations in functioning due to physical difficulties (4 questions), limitations in functioning due to emotional difficulties (three questions), energy, ie exhaustion (4 questions), emotional well-being (5 questions), social functioning (2 questions), pain (2 questions), general health (5 questions). Assessment of depression Beck Depression Scale (8), which consists of 21 items, which determine the presence or degree of symptoms of depression. The items are formulated to represent four groups of symptoms - emotional, cognitive, motivational, and physiological. Each item consists of four statements sorted by the severity of a particular symptom of depression and is scored from 0 to 3 , so the range of results can range from 0 to 63 . Respondents who score from 0 to 10 are included in the group of subjects without depressive problems, while respondents with a score of 11 or more belong to the group with depressive disorders.

\section{Statistical analysis}

The data processing procedure was performed through the software package SPSS version 20, and descriptive statistical measures, correlation analysis, Mann-Whitney U test, and Kruskal-Wallis test were used for the analysis of the collected data.

\section{RESULTS}

The study included 60 people diagnosed with lung or breast cancer. The sample included the same number of men and women (30 women and 30 men) (Figure 1).

The youngest respondent was 32 years old and the oldest 83 . The average age of the respondents was 56.80 years $(\mathrm{SD}=12.64)$. The differences in the average age of men $(x=33.50, S D=13.18)$ and women $(x$ $=54.63, \mathrm{SD}=11.89)$ were not statistically significant $(p=0.186)$. The largest number of respondents is in the age category up to 49 years (Figure 2).

The theoretical values of each of the SF domains can range from 0 to 100 , with higher values indicating a better quality of life. From the data presented in Table 1, we notice that the maximum values of the distribution of all domains in our sample are less than the maximum theoretical value. In the total sample of respondents, the domain of physical functioning had the highest value with a median of 55, while the domain of energy/exhaustion had the lowest value with a median of 17.50 . There is no statistically significant difference in the quality of life assessments between men and women.

The presence of complications is a statistically significant source of differences in the domain of total physical score and is not a statistically significant source of differences in other domains from the SF36 questionnaire (Table 2).

Based on the data from the previous table, we can see that the values on the Beck Depression Inventory range from 23 to 35 , with $\mathrm{AS}=30.00$ and $\mathrm{SD}=2.584$.

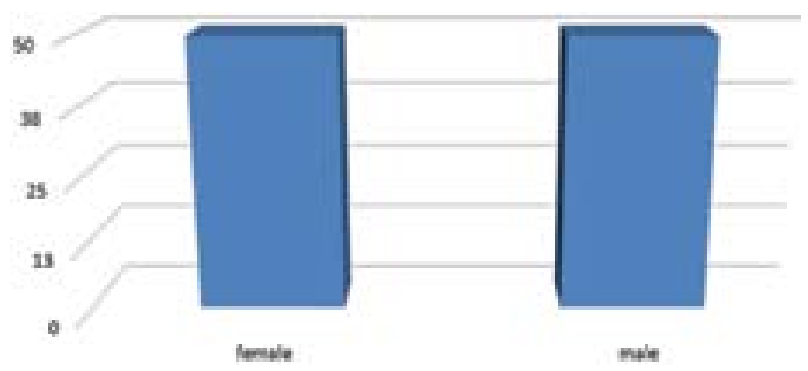

Figure 1. Gender structure of patients

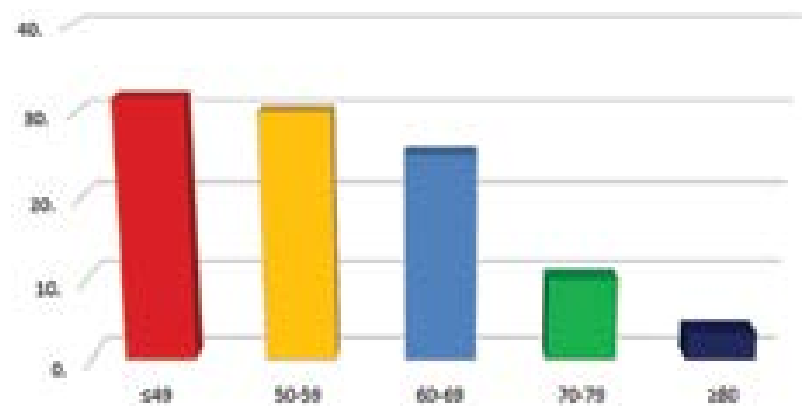

Figure 2. Age structure of patients 
Table 1. Values of all SF questionnaire domains

\begin{tabular}{|l|c|c|c|c|c|}
\hline Variables & AS & SD & M & Min & Max \\
\hline Physical functioning & 52.42 & 10.75 & 55 & 25 & 75 \\
\hline Restrictions due to physical t. & 33.33 & 17.63 & 25 & 0 & 75 \\
\hline Limitations due to emotional problems & 21.11 & 16.20 & 33.33 & 0 & 33 \\
\hline Energy / exhaustion & 19.08 & 8.46 & 17.50 & 5 & 45 \\
\hline Emotional well-being & 38.27 & 7.19 & 40.00 & 20 & 56 \\
\hline Social functioning & 38.54 & 11.34 & 37.50 & 13 & 63 \\
\hline Pain & 23.79 & 10.91 & 22.50 & 10 & 55 \\
\hline General health & 27.67 & 7.22 & 27.50 & 15 & 45 \\
\hline Total physical score & 34.30 & 5.78 & 35.00 & 21 & 54 \\
\hline Total mental score & 29.25 & 5.25 & 30.46 & 15 & 40 \\
\hline
\end{tabular}

AS - arithmetic mean, SD - standard deviation, M - median, Min - minimum, Max - maximum

Table 2. Occurrence of complications and average values of domains from the SF36 questionnaire

\begin{tabular}{|c|c|c|c|c|c|c|c|c|}
\hline \multicolumn{2}{|c|}{ Variables } & \multirow{2}{*}{$\begin{array}{c}\text { Median } \\
55\end{array}$} & \multirow{2}{*}{$\begin{array}{c}\text { Min } \\
25\end{array}$} & \multirow{2}{*}{$\begin{array}{c}\text { Max } \\
70\end{array}$} & \multirow{2}{*}{$\begin{array}{c}\text { Rang } \\
45\end{array}$} & \multirow{3}{*}{$\begin{array}{c}\begin{array}{c}\text { Mann- } \\
\text { Whitney } \\
\text { U }\end{array} \\
295.000\end{array}$} & \multirow{3}{*}{$\begin{array}{c}\mathbf{Z} \\
-0.734\end{array}$} & \multirow{3}{*}{$\begin{array}{c}\mathbf{p} \\
0.463\end{array}$} \\
\hline \multirow{2}{*}{$\mathbf{F F}$} & Yes & & & & & & & \\
\hline & No & 55 & 35 & 75 & 40 & & & \\
\hline \multirow{2}{*}{ OF } & Yes & 25 & 0 & 50 & 50 & \multirow{2}{*}{233.000} & \multirow{2}{*}{-1.952} & \multirow{2}{*}{0.051} \\
\hline & No & 50 & 25 & 75 & 50 & & & \\
\hline \multirow{2}{*}{ OE } & Yes & 33.33 & 0 & 33 & 33 & \multirow{2}{*}{322.500} & \multirow{2}{*}{-0.307} & \multirow{2}{*}{0.759} \\
\hline & No & 33.33 & 0 & 33 & 33 & & & \\
\hline \multirow{2}{*}{$\mathbf{E}$} & Yes & 15 & 5 & 40 & 35 & \multirow{2}{*}{230.500} & \multirow{2}{*}{-1.877} & \multirow{2}{*}{0.061} \\
\hline & No & 20 & 5 & 45 & 40 & & & \\
\hline \multirow{2}{*}{ EB } & Yes & 40 & 20 & 52 & 32 & \multirow{2}{*}{285.500} & \multirow{2}{*}{-0.911} & \multirow{2}{*}{0.362} \\
\hline & No & 36 & 24 & 56 & 32 & & & \\
\hline \multirow{2}{*}{ SF } & Yes & 37.50 & 13 & 50 & 37 & \multirow{2}{*}{258.000} & \multirow{2}{*}{-1.439} & \multirow{2}{*}{0.150} \\
\hline & No & 37.50 & 13 & 63 & 50 & & & \\
\hline \multirow{2}{*}{ B } & Yes & 22.50 & 10 & 55 & 45 & \multirow{2}{*}{333.000} & \multirow{2}{*}{-0.079} & \multirow{2}{*}{0.937} \\
\hline & No & 22,50 & 10 & 45 & 35 & & & \\
\hline \multirow{2}{*}{$\mathbf{O Z}$} & Yes & 25 & 15 & 45 & 30 & & & \\
\hline & No & 30 & 15 & 45 & 30 & 251.000 & -1.522 & 0.128 \\
\hline UF & Yes & 33.75 & 21 & 43 & 22 & 204000 & 2 & 0027 \\
\hline $\mathbf{U F}$ & No & 35.63 & 24 & 54 & 30 & 204.000 & -2.285 & 0.022 \\
\hline M & Yes & 30 & 15 & 38 & 23 & 286000 & 0870 & 370 \\
\hline UIV & No & 46 & 24 & 40 & 16 & 200.000 & -0.019 & 0.319 \\
\hline
\end{tabular}

FF - physical functioning, $\mathbf{O F}$ - restrictions due to physical difficulties, $\mathbf{O E}$ - limitations due to emotional problems, $\mathbf{E}$ - energy/ exhaustion, EB - emotional well-being, SF - social functioning, B - pain, $\mathbf{O Z}$ - general health, UF - total physical score, UM - total mental score

Table 3. Assessment of depression

\begin{tabular}{|l|c|c|}
\hline Depression & $\mathbf{N}$ & $\mathbf{\%}$ \\
\hline No depression & 0 & 0 \\
\hline Mild depression & 0 & 0 \\
\hline Mild to moderate depression & 0 & 0 \\
\hline Moderate to severe depression & 23 & 38.3 \\
\hline Expressed depression & 37 & 61.7 \\
\hline$\Sigma$ & 60 & 100 \\
\hline
\end{tabular}


Table 4. Relationship between quality of life and value domains on the Beck Depression Scale

\begin{tabular}{|c|c|c|}
\hline \multirow{2}{*}{$\begin{array}{c}\text { The domain } \\
\text { of quality of life }\end{array}$} & \multicolumn{2}{|c|}{ Beck Depression Scale } \\
\cline { 2 - 3 } & Ro & $\mathbf{P}$ \\
\hline FF & 0.263 & $\mathbf{0 . 0 4 4}$ \\
\hline OF & 0.029 & 0.829 \\
\hline OE & -0.242 & 0.065 \\
\hline E & 0.117 & 0.376 \\
\hline EB & -0.106 & 0.422 \\
\hline SF & -0.214 & 0.103 \\
\hline B & 0.048 & 0.718 \\
\hline OZ & 0.000 & 0.999 \\
\hline UF & 0.153 & 0.248 \\
\hline UM & -0.280 & $\mathbf{0 . 0 3 2}$ \\
\hline
\end{tabular}

FF - physical functioning, $\mathbf{O F}$ - restrictions due to physical difficulties, $\mathbf{O E}$ - limitations due to emotional problems, $\mathbf{E}$ - energy/ exhaustion, EB - emotional well-being, SF - social functioning, B - pain, $\mathbf{O Z}$ - general health, UF - total physical score, UM - total mental score

The obtained results tell us that all respondents from our sample had certain depressive disorders, namely $61.7 \%$ of respondents with pronounced depression, and $38.3 \%$ with moderate to severe depression (Table 3 ).

Based on the data presented in Table 4, it is possible to notice that the correlation between the score on the Beck Depression Inventory and physical functioning is statistically significant at the significance level of 0.05 and that it is positive. Respondents who have a higher score on the Beck Depression Inventoryalso have a higher score on the dimension of physical functioning. Since the obtained correlation coefficient is less than 0.30 , it can be concluded that the level of correlation is low according to the Cohen criterion. Also, the obtained results show that there is a statistically significant correlation between the score on the Beck Depression Inventory and overall mental functioning and that this correlation is negative. The negative sign of the obtained correlation indicates that a high score on the Beck Depression Inventory is followed by a low score on the dimension of overall mental functioning and vice versa. The obtained correlation coefficient is less than 0.30, so it can be concluded that the level of correlation is low according to the Cohen criterion.

\section{DISCUSSION}

Quality of life is a comprehensive satisfaction/ dissatisfaction with one's own life. It is the subjective experience of every human being that undoubtedly depends on the circumstances in which one lives, as well as on the composition of values, expectations, and aspirations. Quality of life refers to personal well-being and life satisfaction, including mental and physical health (9). The study included 60 people diagnosed with lung or breast cancer. Patients facing a diagno- sis of malignancy go through a difficult period of disease acceptance and adjustment (10). The conducted research verified the satisfaction of the respondents with everyday life, the obtained information on medical check-ups, the support of family members as well as the possibilities of self-care, as well as the presence of depression in patients with malignant diseases. The treatment and care of patients with malignant diseases are multidisciplinary, with particular emphasis on the role of the nurse who spends the most time with the patient. In order for the health care process to meet the needs of patients during hospitalisation and after discharge, an important factor is the continuous education of nurses to acquire new knowledge, skills, and abilities. Nurses, in order to improve the quality of life of patients with malignant diseases, must base their daily work on the science of nursing, verified scientific theories, and empiricism (10). Disturbed perception of the appearance of their body, which can result in lower self-esteem and lead to social isolation and impaired quality of life, with negative physical, mental and social consequences for themselves and their family members (11). In our research, the best quality of life was observed in the group of persons with the highest level of education (college and university), while in all three phases of the survey, statistically, significantly lower values were found in persons with completed or incomplete primary school. Lundy and co-workers believe that the level of education should be viewed in the context of income because it is largely conditioned, and lower-income has a negative impact on all aspects of quality of life (12).

Statistically significantly lower values were found in the domain of limitations in functioning due to emotional problems, which indicates that it is necessary to provide patients with psychosocial support after treatment. In the psychological sense, adaptation implies the adaptation of an individual to his environment or the circumstances in which he finds himself, and it includes physical, cognitive, and emotional factors. The obtained results tell us that all respondents from our sample have certain depressive disorders, namely $61.7 \%$ of respondents with pronounced depression, and $38.3 \%$ with moderate to severe depression. Aminisani and colleagues state in their paper that anxiety and depression are considered the most common mental disorders in people with malignant diseases, citing data from the literature that the prevalence of clinical depression among cancer patients ranges between 13$40 \%$; depression is associated by some authors with higher mortality rates $(13,14)$. In our study, the highest values of the Beck Depression Scale were found in the elderly, respondents in the widow/widower group, and people with the lowest level of education; gender and 
place of residence did not have a significant impact on the values of this instrument. Respondents who have a higher score on the Beck Depression Scale also have a higher score on the physical functioning dimension. Patients who have signs of depression have a significantly poorer quality of life. Women diagnosed with breast cancer face a number of challenges that impair their mental health and thus their quality of life. Factors that are important for mental health are the occurrence of depression and anxiety, stress, and a distorted body image. Diagnosis, treatment decisions, and outcome care and prognosis produce significant stress $(15,16$, 17). Depression and anxiety occur depending on the treatment. Research has focused on the aspect of personality that is thought to support the mental health of women with breast cancer, and that aspect is optimism (18). As mental health intertwines with the quality of life, poorer mental functioning leads to lower quality of life. Quality of life based on the health of people with malignancy must be the goal and end result of the rehabilitation process for every patient with malignancy $(19,20,21,22)$.

\section{CONCLUSION}

Respondents who have a higher score on theBeck Depression Inventory also have a higher score on the dimension of physical functioning. Recognising the importance of the impact of physical health on mental health and the link between mental health and physical health, the treatment of breast cancer strives to maintain a quality of life as high as possible. To achieve this, health care must be at the highest possible level, and the education of medical staff is needed through regular education and additional education related to communication skills and psychological aspects of the health of people with cancer.

Conflict of Interests: The authors declare that there are no conflicts of interest related to this article.

Funding: None

\section{Licensing}

This work is licensed under a Creative Commons Attribution 4.0 International (CC BY 4.0) License.

\title{
Sažetak
}

\section{PROCENA KVALITETA ŽIVOTA PACIJENATA OBOLELIH OD KARCINOMA DOJKE I PLUĆA}

\author{
Kalajdzic Olivera, ${ }^{1}$ Pavlovic Jelena ${ }^{2}$ \\ ${ }^{1}$ Department of Psychology, University of East Sarajevo, Faculty of Medicine in Foca, Bosnia and Herzegovina \\ ${ }^{2}$ Department of Nursing, University of East Sarajevo, Faculty of Medicine in Foca, Bosnia and Herzegovina
}

Uvod: Procena kvaliteta života važan je predmet istraživanja u raznim disciplinama i danas je sastavni deo evaluacije rehabilitacionih i terapijskih postupaka. Cilj studije bio je proceniti kvalitet života i uticaj depresije na kvalitet života kod pacijenata s rakom dojke i pluća.

Materijal i metode: Studija je obuhvatila 60 osoba, od kojih je 30 sa dijagnostikovanim rakom pluća, a 30 sa dijagnostifikovanim rakom dojke. Upitnik su sastavili istraživači za potrebe ovog istraživanja. Procena kvaliteta života Upitnik za ocenu kvaliteta života SF-36. I procena depresije Beckova skala depresije.

\section{REFERENCES}

1. Lin JS, Piper MA, Perdue LA, Rutter C, Webber EM, O'Connor E, et al. Screening for colorectal cancer: updated evidence report and systematic review for the US preventive services task force. JAMA. 2016; 315(23): 2576-94. doi: 10.1001/ jama.2016.3332.

2. World Health Report: life in the 21 st century-a vision for all. Geneva: WHO. 1998. https://www.who.int/whr/1998/en/.
Rezultati: Prisustvo komplikacija je statistički značajan izvor razlika u domenu ukupnog fizičkog rezultata i nije statistički značajan izvor razlika u drugim domenima iz upitnika SF36. Na osnovu podataka iz prethodne tablice možemo videti da se vrednosti na Beckovoj skali depresije kreću od 23 do 35 , s AS = 30,00 i $\mathrm{SD}=2,584$.

Zaključak: Ispitanici koji imaju viši rezultat na Beckovoj skali depresije imaju i veći rezultat na dimenziju fizičkog funkcionisanja.

Ključne reči: kvalitet života, maligne bolesti, depresija, bolesnici.

3. WHOQOL Group. Study protocol for the World Health Organization project to develop a quality of life assessment instrument (WHOQOL). Qual Life Res. 1993; 2(2): 153-9.

4. Hengelson VS. Social support and quality of life. Qual Life Res. 2003; 12 (Suppl 1): 25-31. doi: 10.1023/a:1023509117524.

5. Andrews L. Systematic review summary - Psychosocial interventions to improve quality of life and emotional well-being for recently diagnosed cancer patients. Singapore Nursing Journal 2013; 40(3): 12-33. 
6. Barre VP, Padmaja G, Saxena RK, Rana S. Impact of medical intervention on stress and quality of life in patients with cancer. Indian J Palliat Care. 2015; 21(2): 203-8. doi: 10.4103/0973-1075.156503.

7. Ware JE, Snow KK, Kosinski M, Gandek B, New England Medical Center. The Health Institute. SF-36 Health Survey: Manual and Interpretation Guide. Boston: The Health Institute, New England Medical Center; 1993.

8. Beck AT, Ward CH, Mendelson M, Mock J, Erbaugh J. An inventory for measuring depression. Arch Gen Psychiatry. 1961; 4:561-71. doi: 10.1001/archpsyc.1961.01710120031004.

9. Kugler S. Quality of life and standards for quality. E Quality 2001; 2:70-2.

10. Guldbrandt LM. The effect of direct referral for fast CT scan in early lung cancer detection in general practice. A clinical, cluster-randomised trial. Dan Med J 2015; 62(3): B5027.

11. Urbania TH, Dusendang JR, Herrinton LJ, Alexeeff S, Corley DA, Ely S, et al. Standardized reporting and management of suspicious findings on chest CT imaging is associated with improved lung cancer diagnosis in an observational study. Chest. 2020; 158 (5): 2211-20. doi: 10.1016/j.chest.2020.05.595.

12. Fevrier HB, Liu L, Herrinton LJ, Li D. A transparent and adaptable method to extract colonoscopy and pathology data using natural language processing. J Med Syst. 2020; 44(9): 151. doi: 10.1007/s10916-020-01604-8.

13. Aminisani N, Nikbakht $H$, Asghari Jafarabadi $M$, Shamshirgaran SM. Depression, anxiety, and health-related quality of life among colorectal cancer survivors. J Gastrointest Oncol. 2017; 8(1): 81-8. doi: 10.21037/jgo.2017.01.12.

14. Cordero A, Villar MJ, Sanchez NM, Pimentel MN, Garcia ML, Gomez V. Breast cancer and body image as a prognostic factor of depression: a case study in México City Nutr Hosp. 2014; 31(1):371-9. doi: 10.3305/nh.2015.31.1.7863.

\section{Correspondence to/Autor za korespondenciju}

Dr. Olivera Kalajdžić, Faculty of Medicine in Foca, University of East Sarajevo, Bosnia and Herzegovina, Department of Psychology

Studentska 5, 73300 Foca, Bosnia and Herzegovina E-mail: olivera.kalajdzic@yahoo.com
15. Colby D, Shifren K. Optimism, mental health, and quality of life: A study among breast cancer patients. Psychol Health Med. 2013; 18(1): 10-20. doi: 10.1080/13548506.2012.686619.

16. Corwin D, Wall K, Koopman C. Psychospiritual integrative therapy: Psychological intervention for women with breast cancer. The journal of specialists in group work 2012; 37(3): 252 -73.doi: 10.1080/01933922.2012.686961.

17. Fox JP, Philip EJ, Gross CP, Desai RA, Killelea B, Desai MM. Associations between mental health and surgical outcomes among women undergoing mastectomy for cancer. Breast J. 2013; 19(3): 276-84. doi: 10.1111/tbj.12096.

18. Gopie JP, Kuile MM, Timman R, Mureau MA, Tibben A. Impact of delayed implant and DIEP flap breast reconstruction on body image and sexual satisfaction: a prospective follow-up study. Psychooncology. 2014; 23(1): 100 -7. doi: 10.1002/pon.3377.

19. Kvillemo P, Branstrom R. Copingwith breast cancer: A meta-analysis. PLoS ONE. 2014; 9(11):e112733. doi: 10.1371/ journal.pone.0112733.

20. McKean LN, Newman EF, Adair P. Feeling like me again: a grounded theory of the role of breast reconstruction surgery in self-image. Eur J Cancer Care (Engl). 2013; 22(4): 493-502. doi: 10.1111/ecc.12055.

21. Mosewich AD, Hadd V, Crocker P, Zumbo B. Invariance testing of the SF-36 health survey in women breast cancer survivors: Do personal and cancer-related variables influence the meaning of quality of life items? Soc Indic Res 2013; 110(2): 559-77.doi: 10.1007/s11205-011-9944-0.

22. Przezdziecki A, Sherman K, Baillie A, Taylor A, Foley E, Stalgis BK. My changed body: breast cancer, body image, distress, and self-compassion. Psycho-Oncology. 2013; 22(8): 1872 -9. doi: $10.1002 /$ pon. 3230 . 